\title{
Studi Akurasi Citra Landsat 8 dan Citra MODIS untuk Pemetaan Area Terbakar (Studi Kasus: Provinsi Riau)
}

\author{
Agita Setya Herwanda, Bangun Muljo Sukojo \\ Jurusan Teknik Geomatika, Fakultas Teknik Sipil dan Perencanaan, Institut Teknologi Sepuluh \\ Nopember (ITS) \\ Jl. Arief Rahman Hakim, Surabaya 60111 Indonesia \\ e-mail: bangunms@gmail.com
}

\begin{abstract}
Abstrak - Kebakaran hutan dan lahan telah menjadi ancaman yang cukup serius bagi masyarakat secara global pada satu dekade terkahir, hal ini berkaitan erat dengan rusaknya lingkungan dan sumber daya alam yang ada di dunia terutama pada Negara tropis yang memiliki banyak hutan seperti Indonesia. Provinsi Riau merupakan salah satu dari delapan provinsi yang dinyatakan rawan terhadap bencana kebakaran hutan. Dalam penelitian ini akan dilakukan pengolahan citra satelit dengan resolusi spasial yang berbeda dan menggunakan metode yang sama untuk mendapatkan hasil yang sama yaitu area terbakar. Citra yang digunakan adalah citra Landsat 8 dengan resolusi spasial $30 \mathrm{~m}$ dan citra MODIS dengan resolusi spasial $250 \mathrm{~m}$ menggunakan metode NBR (Normalized Burned Ratio). Dengan membandingkan kedua data yang berbeda tersebut maka dapat ditentukan penilaian akurasi dari kedua citra yang memiliki resolusi berbeda. Penilaian akurasi yang akan dicapai adalah luasan burned area agreement, related comission error, related omission error, independent omission error. Hasil dari penelitian ini menunjukkan luas area terbakar hasil klasifikasi citra Landsat 830 m adalah 125.923,790 Hektar, luas area terbakar hasil klasifikasi citra MODIS $250 \mathrm{~m}$ adalah 171.045,154 Hektar. Sedangkan hasil penilaian akurasi dari citra MODIS dan citra Landsat 8 didapatkan hasil luas burned area agreement 40.200,882 Hektar, related comission error 94.633,149 Hektar, related omission error 44.744,897 Hektar, independent comission error 23.165,602 Hektar, dan independent ommission error 21.766,780 Hektar.
\end{abstract}

Kata Kunci- Landsat 8, MODIS, Normalized Burn Ratio

\section{PENDAHULUAN}

$\mathrm{P}$ ADA tahun 2014, sebuah sistem online Global Forest Watch yang menggunakan data dari NASA mendeteksi bahwa Negara Indonesia telah kehilangan hutan sebanyak 1.490 .457 hektar wilayah hutannya. Angka tersebut meningkat sejak tahun 2001 dimana pada tahun tersebut terdapat 745.239 hektar wilayah hutan yang hilang. Penyebab dari hilangnya hutan di Indonesia antara lain karena adanya penebangan hutan liar, pembukaan lahan maupun kebakaran hutan. Kebakaran hutan yang terjadi pada tahun 2014 sebagian besar terjadi di Sumatera dan Kalimantan. Kebakaran hutan di Sumatera dan Kalimantan meningkat sepanjang musim kemarau sekitar bulan April hingga Oktober. Delapan provinsi di Sumatera dan Kalimantan yang ditetapkan sebagai daerah rawan kebakaran hutan dan lahan adalah Riau, Jambi, Sumatera Selatan, Lampung, Kalimantan Barat, Kalimantan Tengah, Kalimantan Timur dan Kalimantan Selatan [1]. Salah satu provinsi yang mengalami kebakaran adalah provinsi Riau. Pada tahun 2014, terdapat 230.139 hektar hutan dan lahan yang hilang akibat kebakaran hutan.

Pengukuran area terbakar secara langsung di lapangan, selain relatif mahal, juga memerlukan waktu yang lama. Lebih-lebih dilakukan pada wilayah yang luas dan sulit terjangkau. Salah satu alternatif metode yang dapat dilakukan untuk penyediaan informasi daerah bekas kebakaran hutan dan lahan secara relatif lebih cepat, dapat dilakukan secara serentak pada daerah yang relatif luas dan sulit terjangkau, biaya yang relatif lebih murah serta dengan tingkat akurasi yang dapat dipertanggungjawabkan adalah dengan memanfaatkan citra penginderaan jauh [1].

Berdasarkan hasil-hasil penelitian sebelumnya dapat diketahui bahwa data penginderaan jauh yang digunakan untuk analisis burned area sebagian besar berupa data optis dengan berbagai tingkat resolusi spasial seperti MODIS, Landsat, VIIRS hingga Ikonos dan Quickbird. Burned area dapat dianalisis berdasarkan perubahan nilai reflektansi, indeks vegetasi, dan indeks-indeks lainnya seperti NBR (Normalized Burn Ratio) [3]

Dalam penelitian ini akan dilakukan pengolahan citra satelit dengan resolusi spasial yang berbeda dan menggunakan metode yang sama untuk mendapatkan hasil yang sama yaitu area terbakar. Citra yang digunakan adalah citra Landsat 8 dengan resolusi spasial 30 m menggunakan metode NBR (Normalized Burned Ratio) dan citra MODIS (Moderate Resolution Imaging Spectroradiometer) dengan resolusi spasial $250 \mathrm{~m}$ menggunakan metode NBR (Normalized Burned Ratio). Penggunaan citra Landsat 8 dan citra MODIS dipilih dengan mempertimbangkan kelanjutan dari penelitian sebelumnya karena kedua citra ini memiliki resolusi temporal yang tetap dan setiap bulan dapat dilakukan pemantauan lebih lanjut serta memiliki cakupan yang cukup luas. Dengan membandingkan kedua data yang berbeda tersebut maka dapat ditentukan penilaian akurasi dari kedua citra yang memiliki resolusi berbeda. Penilaian akurasi yang akan dicapai adalah luasan burned area agreement, related comission error, related omission error, independent comission error dan independent omission error.

\section{METODOLOGI PENELITIAN}

\section{A. Lokasi Penelitian}

Lokasi penelitian ini dilakukan di Provinsi Riau. Secara geografis tertetak pada koordinat antara $1^{\circ} 15^{\prime}$ ' Lintang Selatan sampai $4^{\circ} 45^{\prime}$ Lintang Utara atau antara $100^{\circ} 3^{\prime}$ - $109^{\circ} 19^{\prime}$ Bujur Timur seperti yang ditunjukkan pada Gambar 1 . 


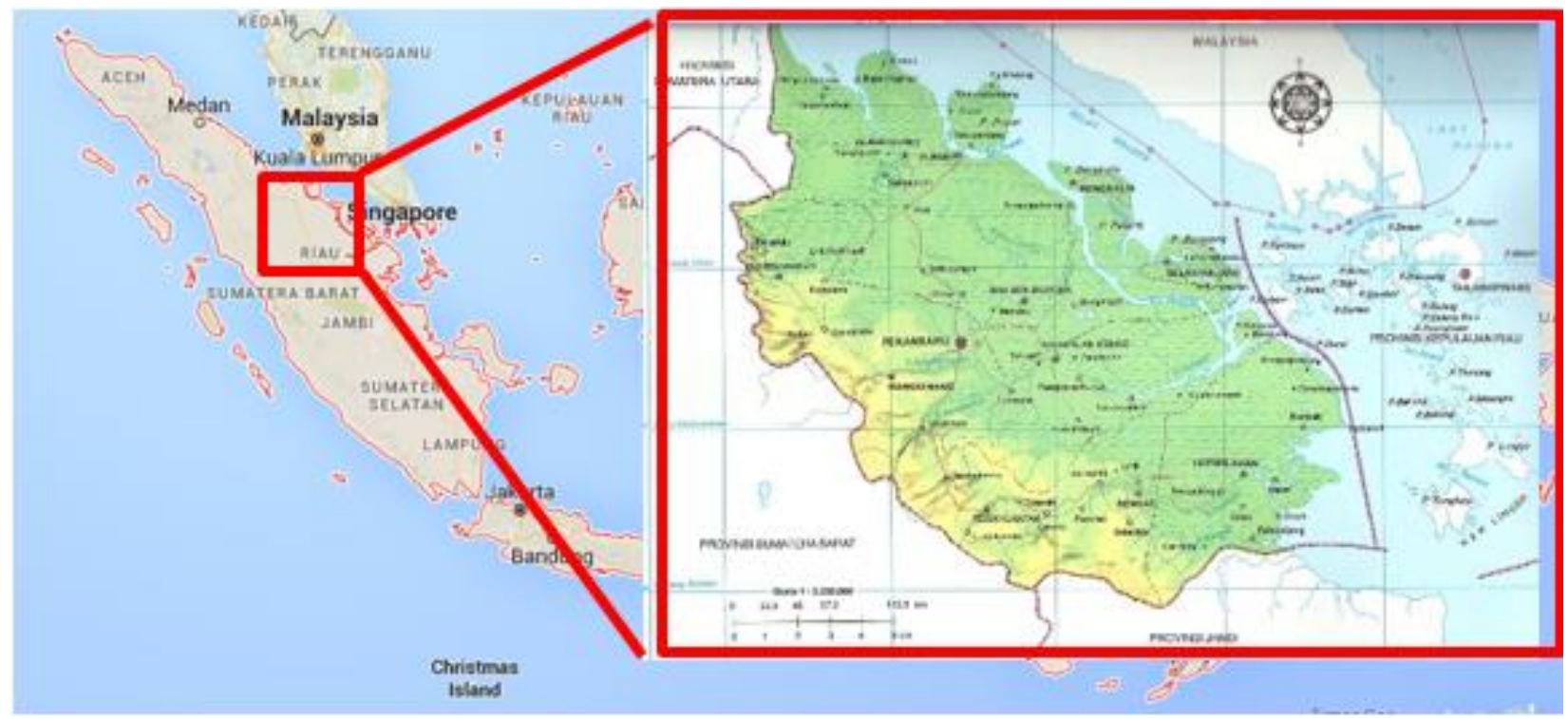

Gambar 1. Lokasi penelitian

(Sumber : Badan Informasi Geospasial)

\section{B. Data dan Peralatan}

\section{a. Data}

Data yang digunakan dalam penelitian tugas akhir ini yaitu:

1. Citra MODIS wilayah Provinsi Riau pada tahun 2014

2. Citra Landsat 8 wilayah Provinsi Riau pada tahun 2014

3. Data Hotspot Provinsi Riau pada tahun 2014

4. Data Vektor batas wilayah Indonesia 2010

b. Peralatan

Peralatan yang digunakan dalam penelitian tugas akhir ini yaitu:

1. Perangkat Lunak (sofware) yang digunakan dalam pengerjaan tugas akhir ini antara lain:

i. ArcGIS 10.2.2

ii. Perangkat lunak pengolah citra

\section{Tahap Pengolahan Data}

Adapun tahap pelaksanaan penelitian ini dapat dilihat pada gambar 2.

a. Data

Data-data yang akan diolah meliputi data citra MODIS 1B, citra Landsat 8 1G dan data hotspot Provinsi Riau tahun 2014.

b. Pola sebaran hotspot temporal dan spasial

Menentukan pola sebaran hotspot secara temporal dalam kurun waktu satu tahun dalam bentuk grafik data statistik untuk mendapatkan bulan puncak kebakaran (peak fire) dan data spasial hotspot puncak kebakaran.

\section{c. Pemilihan citra MODIS dan citra Landsat 8}

Citra MODIS dan citra Landsat 8 dipilih masing-masing pada bulan sebelum puncak kebakaran dan pada bulan sesudah puncak kebakaran di Provinsi Riau tahun 2014.

d. Koreksi geometrik dan koreksi radiometrik

Koreksi geometrik dilakukan pada citra MODIS menggunakan file geolokasi yang terdapat pada citra dengan metode bow tie dan pada citra Landsat 8 tidak dilakukan koreksi geometric karena pada level $1 \mathrm{G}$ sudah terkoreksi secara geometric. Sedangkan koreksi radiometrik dilakukan untuk mengubah nilai digital number menjadi nilai reflektan.

\section{e. Perhitungan nilai normalized burn ratio}

Melakukan perhitungan nilai normalized burn ratio pada citra MODIS dan citra Landsat 8 untuk kemudian dilakukan klasifikasi area terbakar. Area terbakar diidentifikasi berdasarkan nilai threshold $(t)$ dimana threshold yang digunakan untuk menentukan area terbakar adalah $\mu-1 \sigma$.

$\mathrm{NBR}=\frac{\mathrm{NIR}-\mathrm{SWIR}}{\mathrm{NIR}+\mathrm{SWIR}}$

Dimana NIR adalah nilai reflektansi band NIR (Near Infrared) dan SWIR adalah nilai reflektansi band SWIR (Short Wave Infrared).

$\Delta \mathrm{NBR}=N B R_{2}-N B R_{1}$

Dimana NBR1 adalah nilai NBR sesaat sebelum terbakar dan NBR2 adalah nilai NBR sesaat setelah terbakar.

f. Identifikasi Area Terbakar

Area terbakar diidentifikasi berdasarkan model ambang batas (tresholds) $\mu-1 \sigma$. Sebuah piksel (Xij) dinyatakan sebagai area terbakar apabila memenuhi persyaratan:

$\mathrm{Xij}<\mathrm{t}_{\mathrm{BA}}$

Dimana $\mathrm{t}_{\mathrm{BA}}$ merupakan niali ambang batas (tresholds) dari suatu piksel yang dinyatakan sebagai area terbakar.

g. Pemrosesan Spasial

Pemrosesan spasial data antara data area terbakar MODIS 250 $\mathrm{m}$ dan area terbakar Landsat $30 \mathrm{~m}$ untuk mendapatkan area burned area agreement, related commission error, related omission error, independent omission error dan independent omission error lalu dibuat grafik perbandingan luasnya pada masing-masing kota di Provinsi Riau.

\section{h. Kartografi}

Burned area agreement merupakan perpotongan kedua citra area terbakar MODIS $250 \mathrm{~m}$ dan citra Landsat $30 \mathrm{~m}$ dilakukan 
proses kartografi untuk menghasilkan Peta Area Terbakar

Provinsi Riau tahun 2014.

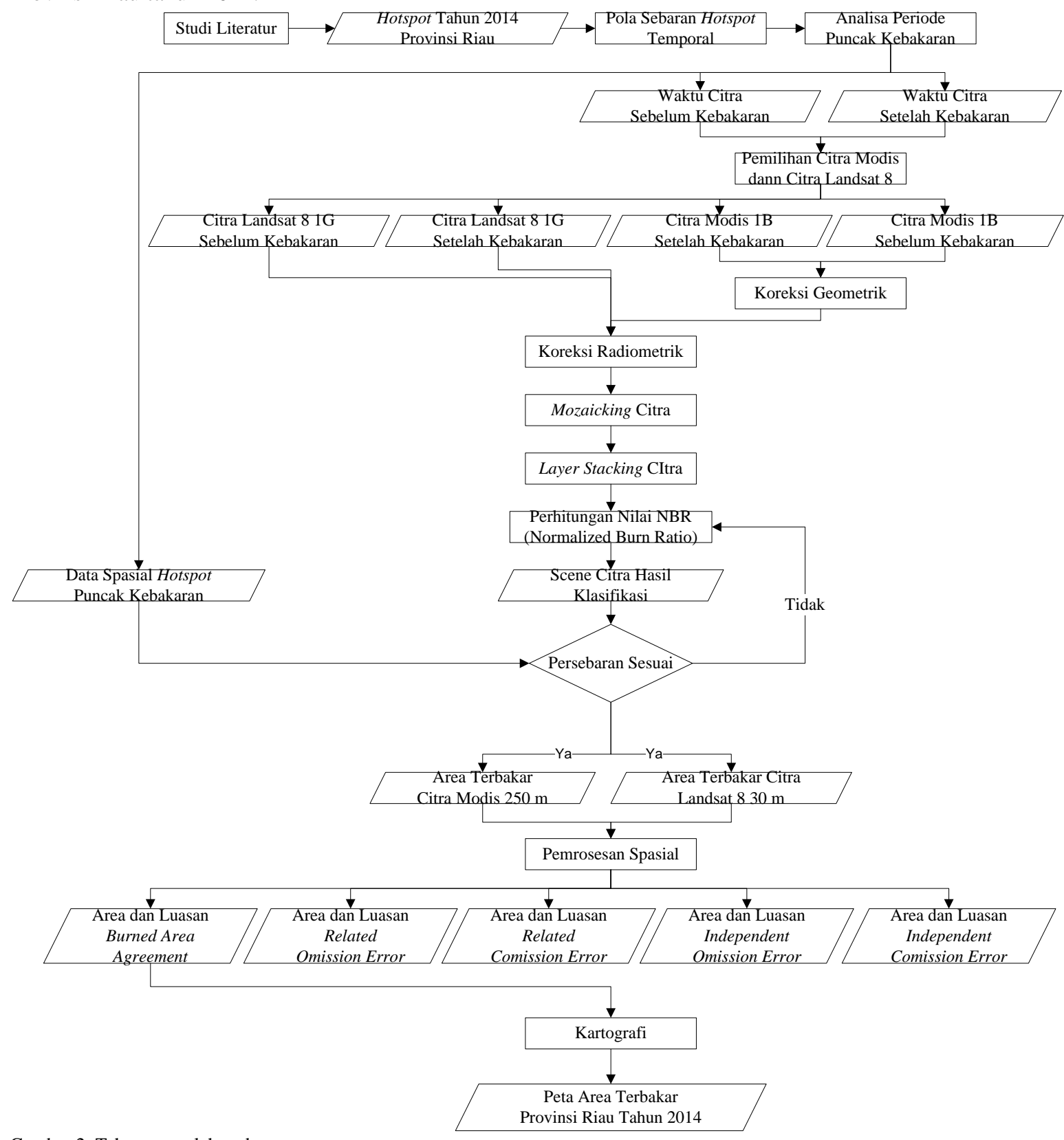

Gambar 2. Tahap pengolahan data

\section{HASIL DAN PEMBAHASAN}

\section{A. Pola Sebaran Hotspot Temporal dan Sebaran Hotspot Spasial}

Hasil pola sebaran hotspot temporal dihasilkan dari pengolahan data hotspot secara temporal di Provinsi Riau pada tahun 2014 dari bulan januari s/d desember. Pola sebaran hotspot temporal digunakan untuk menentukan waktu terjadinya puncak kebakaran (peak fire). Hasil pola sebaran hotspot spasial dihasilkan dari pengolahan data hotspot temporal yaitu pada hotspot bulan peak fire, bulan pre peak fire dan bulan post peak fire. Pola sebaran hotspot spasial peak fire nantinya akan digunakan untuk validasi persebaran area terbakar dan untuk mengetahui berapa jumlah hotspot pada masing-masing daerah.

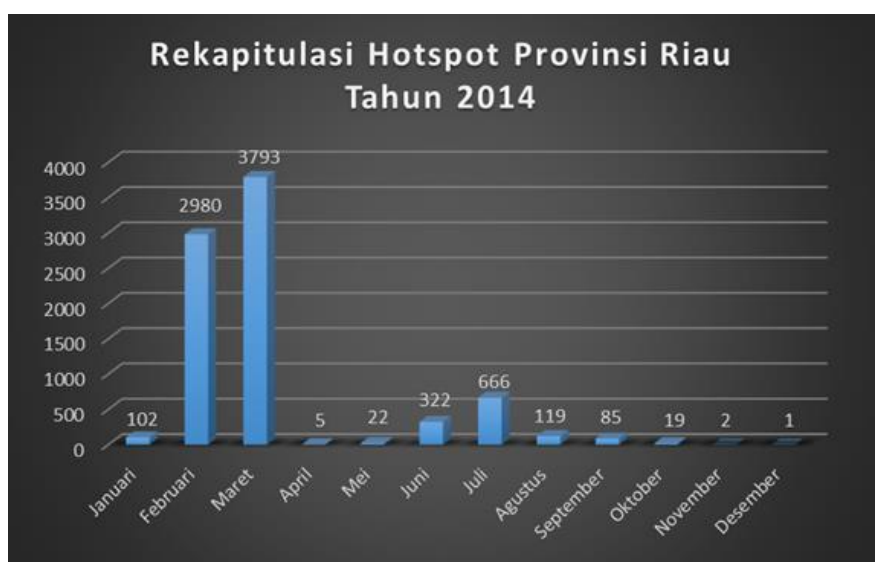

Gambar 3. Pola sebaran hotspot temporal 
Dari hasil sebaran hotspot temporal dapat diketahui bahwa titik hotspot tertinggi terjadi pada bulan Maret dengan 3729 titik hotspot dan bulan Februari dengan 2980 titik hotspot. Maka dapat disimpulkan bahwa kebakaran telah terjadi pada bulan Februari hingga Maret pada tahun 2014. Dari data tersebut maka ditentukan bulan puncak kebakaran (peak fire) terjadi pada bulan Februari dan Maret tahun 2014. Sedangkan untuk bulan sebelum puncak kebakaran (pre peak fire) terjadi pada bulan januari tahun 2014 dan bulan setelah puncak kebakaran (post peak fire) terjadi pada bulan april tahun 2014.

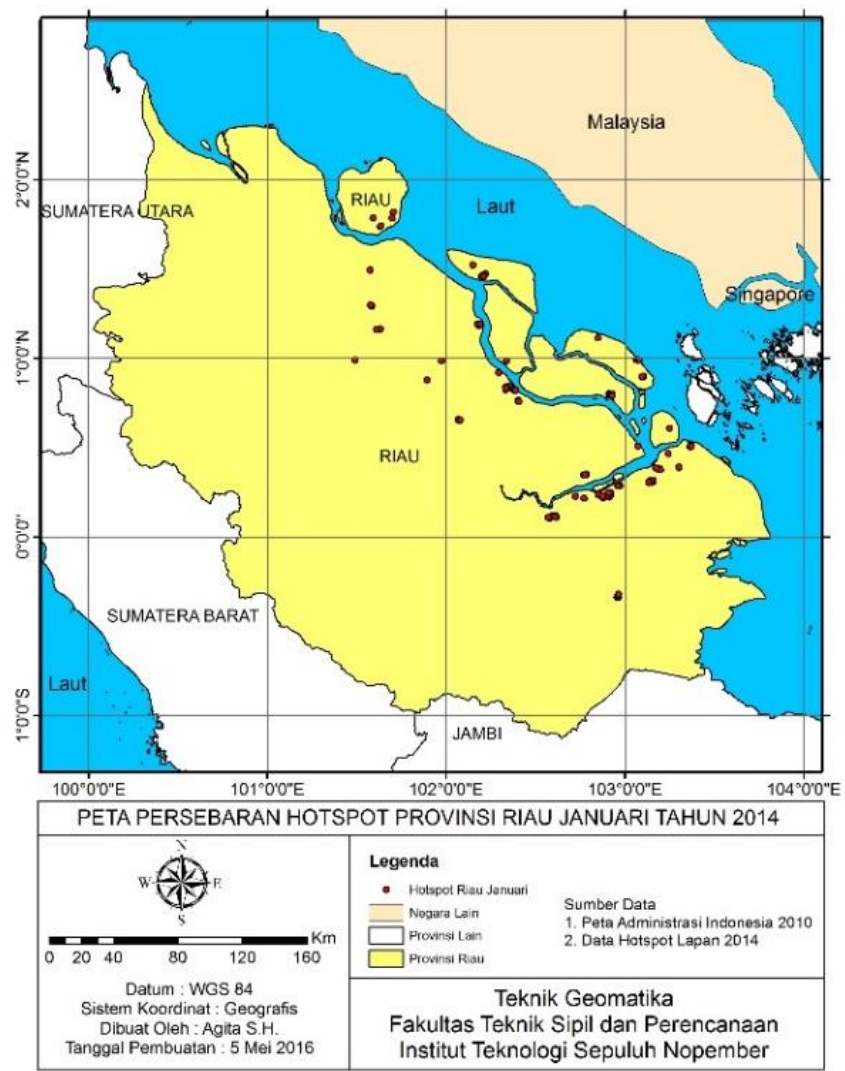

Gambar 4. Hotspot spasial Januari 2014

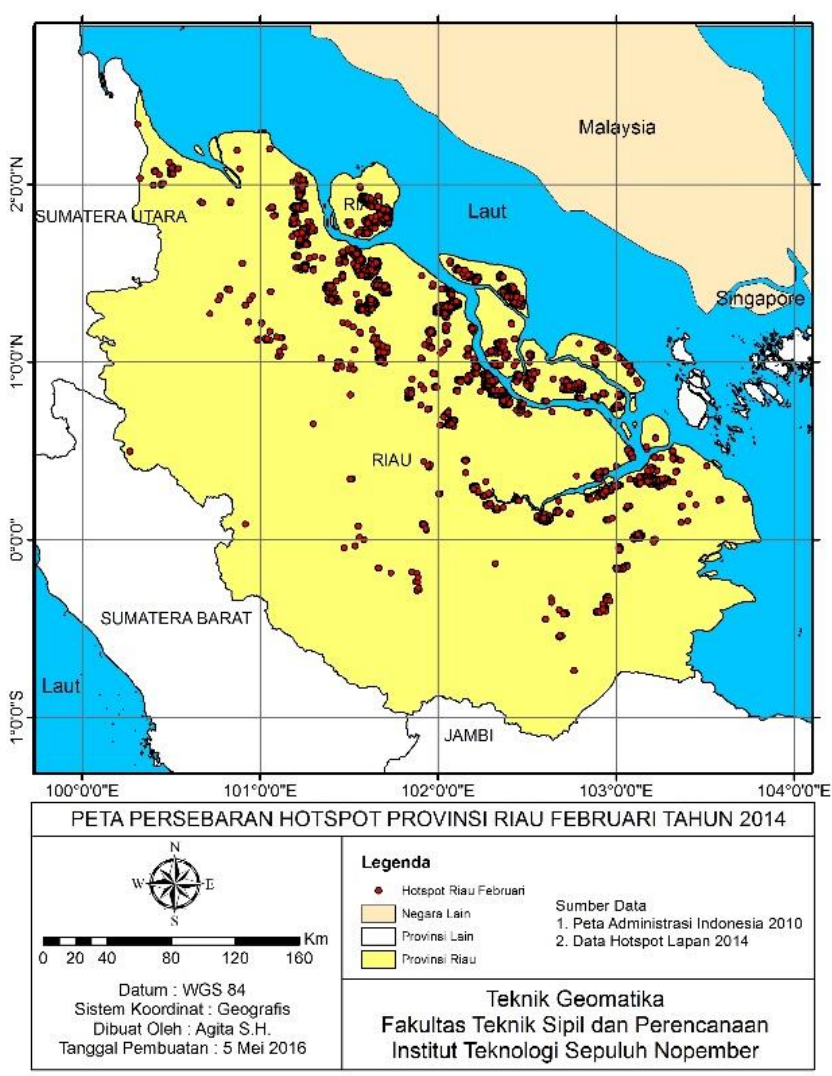

Gambar 5. Hotspot spasial Februari 2014

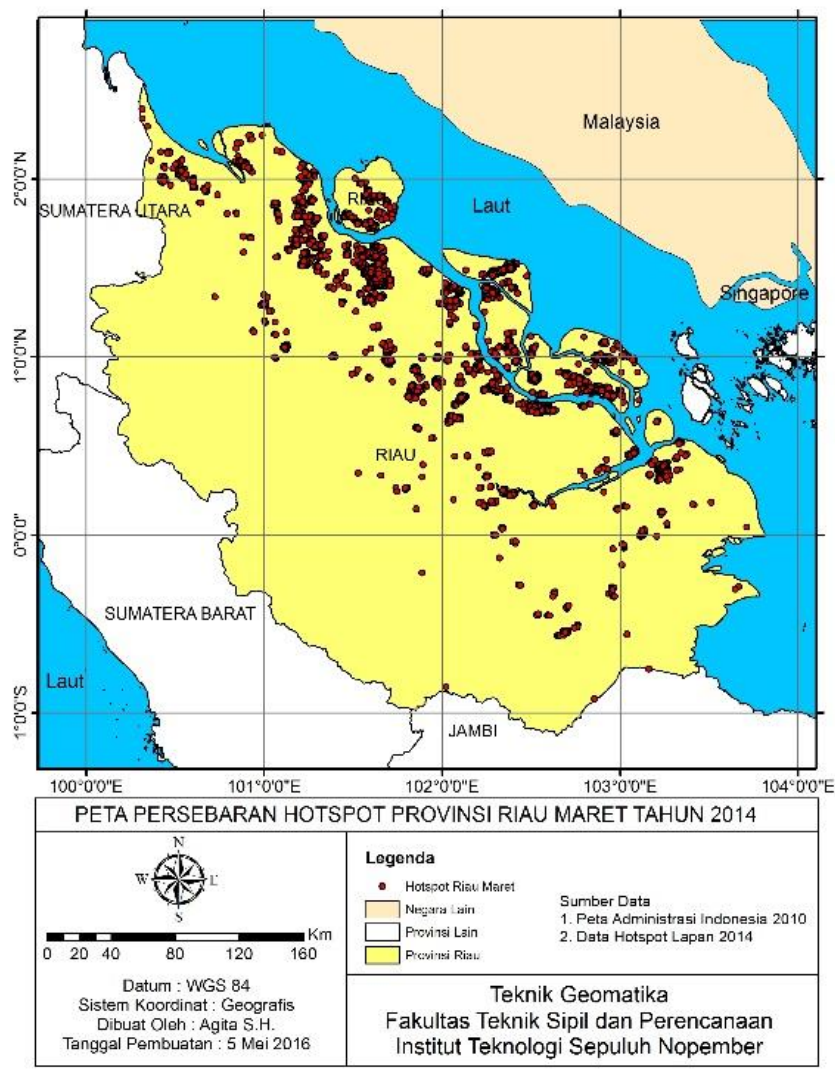

Gambar 6. Hotspot spasial Maret 2014 


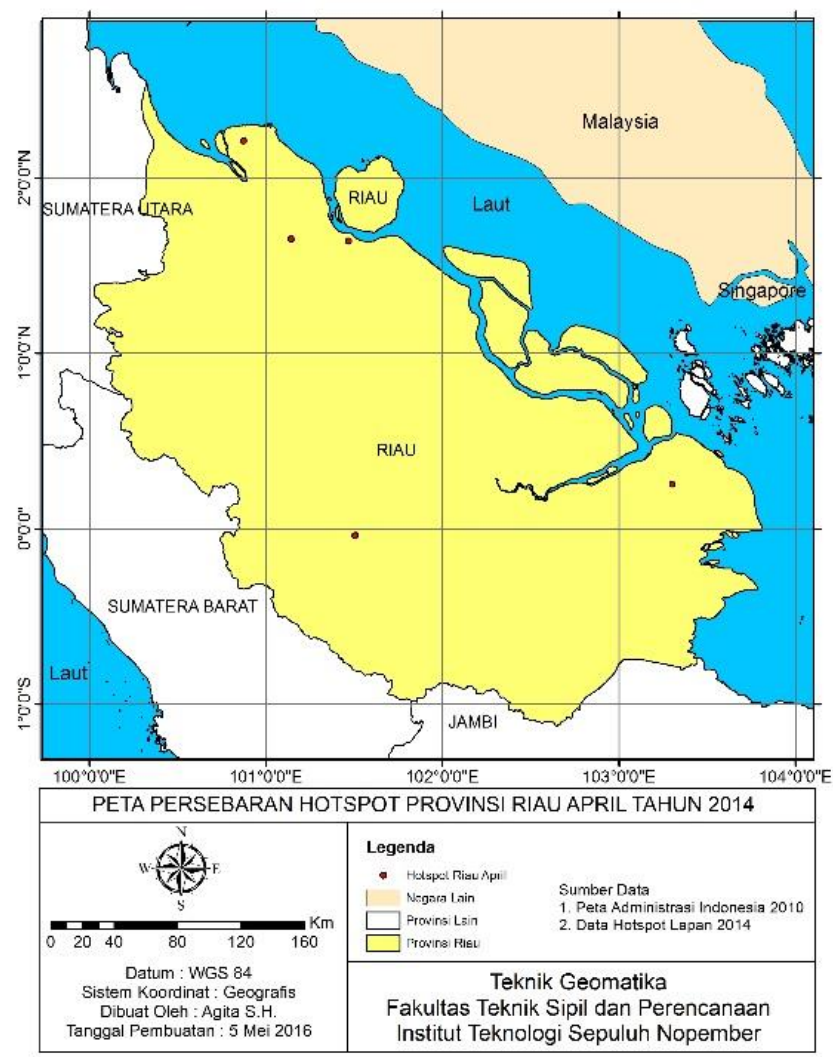

Gambar 7. Hotspot spasial April 2014

Tabel 1.

Hotspot spasial peak fire bulan Maret 2014

\begin{tabular}{cc}
\hline Kabupaten/Kota & Jumlah Hotspot \\
\hline Bengkalis & 875 \\
Indragiri Hilir & 232 \\
Indragiri Hulu & 39 \\
Kampar & 2 \\
Dumai & 1.469 \\
Pelalawan & 173 \\
Rokan Hilir & 297 \\
Siakk & 706 \\
Jumlah & 3.793 \\
\hline \hline
\end{tabular}

Berdasarkan hasil sebaran hotspot spasial dapat diketahui bahawa titik hotspot dengan jumlah terbesar terletak pada Kota Dumai dengan jumlah 1469 titik, Kabupaten Bengkalis dengan 875 titik dan Kabupaten Siakk dengan 706 titik.

\section{B. Penentuan Ambang Batas (Tresholds) Area Terbakar}

Nilai ambang batas dihasilkan dari perhitungan nilai rata-rata $(\mu)$ dan standar deviasi $(\sigma)$ dari hasil pengolahan citra Landsat 8 dan citra MODIS menggunakan algoritma Normalized Burn Ratio. Nilai ambang batas (tresholds) yang akan digunakan dalam penelitian ini adalah $\mu-1 \sigma$. Berikut adalah tabel hasil pengolahan ambang batas yang akan digunakan untuk mengidentifikasi area terbakar:

Tabel 2.

Nilai rata-rata dan standar deviasi indeks NBR

\begin{tabular}{ccccc}
\hline & \multicolumn{2}{c}{ NBR Pre Fire } & \multicolumn{2}{c}{ NBR Post Fire } \\
Citra & $\mu$ & $\sigma$ & $\mu$ & $\sigma$ \\
\hline Landsat 8 & $-0,00414$ & 0,45914 & 0,31942 & 0,56112 \\
MODIS & 0,59967 & 0,12030 & 0,61343 & 0,11045 \\
\hline \hline
\end{tabular}

Tabel 3.

Perubahan nilai rata-rata dan standar deviasi NBR

\begin{tabular}{ccc}
\hline \hline & \multicolumn{2}{c}{ Perubahan } \\
Citra & $\mu$ & $\sigma$ \\
\hline Landsat 8 & 0,32356 & 0,10198 \\
MODIS & 0,01376 & $-0,00986$ \\
\hline
\end{tabular}

Tabel 4.

Nilai ambang batas

\begin{tabular}{ccc}
\hline \hline & \multicolumn{3}{c}{ Ambang Batas $(\mu-1 \sigma)$} \\
Citra & Nilai & Perubahan \\
\hline Landsat 8 & $-0,24170$ & 0,22158 \\
MODIS & 0,50298 & 0,02362 \\
\hline \hline
\end{tabular}

\section{Luas Area Terbakar Citra MODIS dan Citra Landsat 8}

Berdasarkan hasil klasifikasi normalized burn ratio dengan model threshold $\mu-1 \sigma$ pada citra MODIS dan citra Landsat 8 didapatkan hasil area terbakar sebagai berikut.

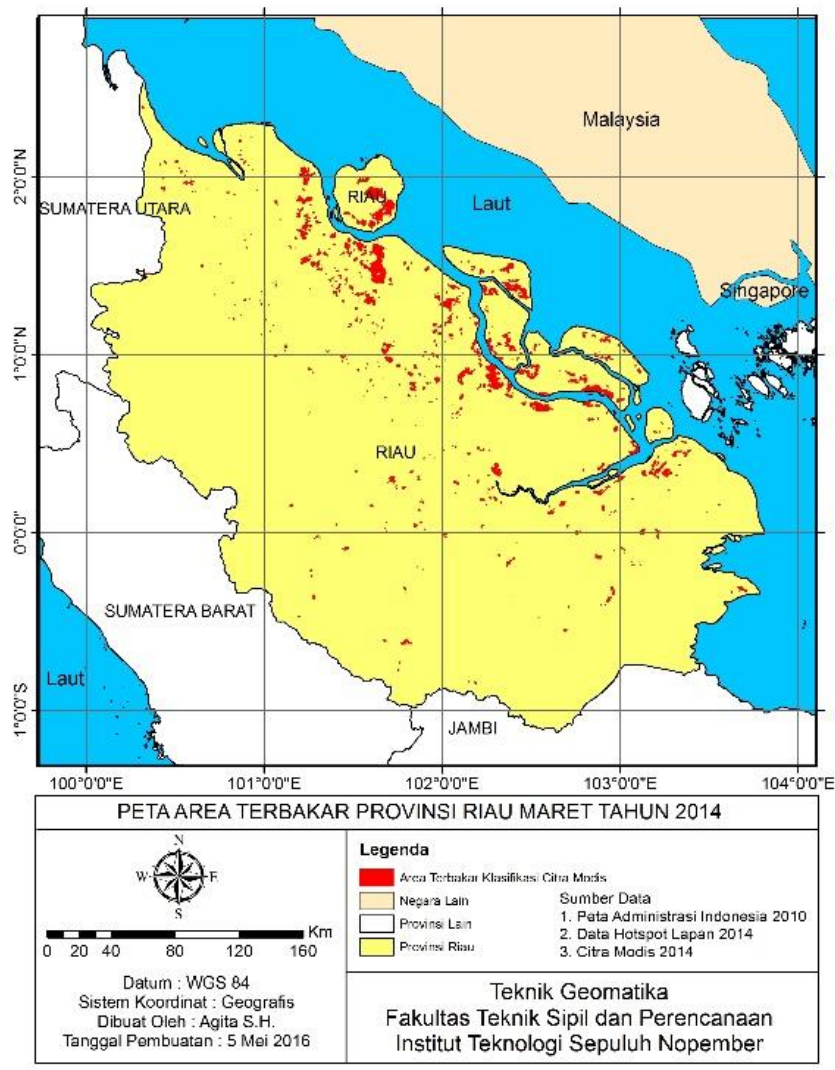

Gambar 8. Area terbakar citra MODIS $250 \mathrm{~m}$ 


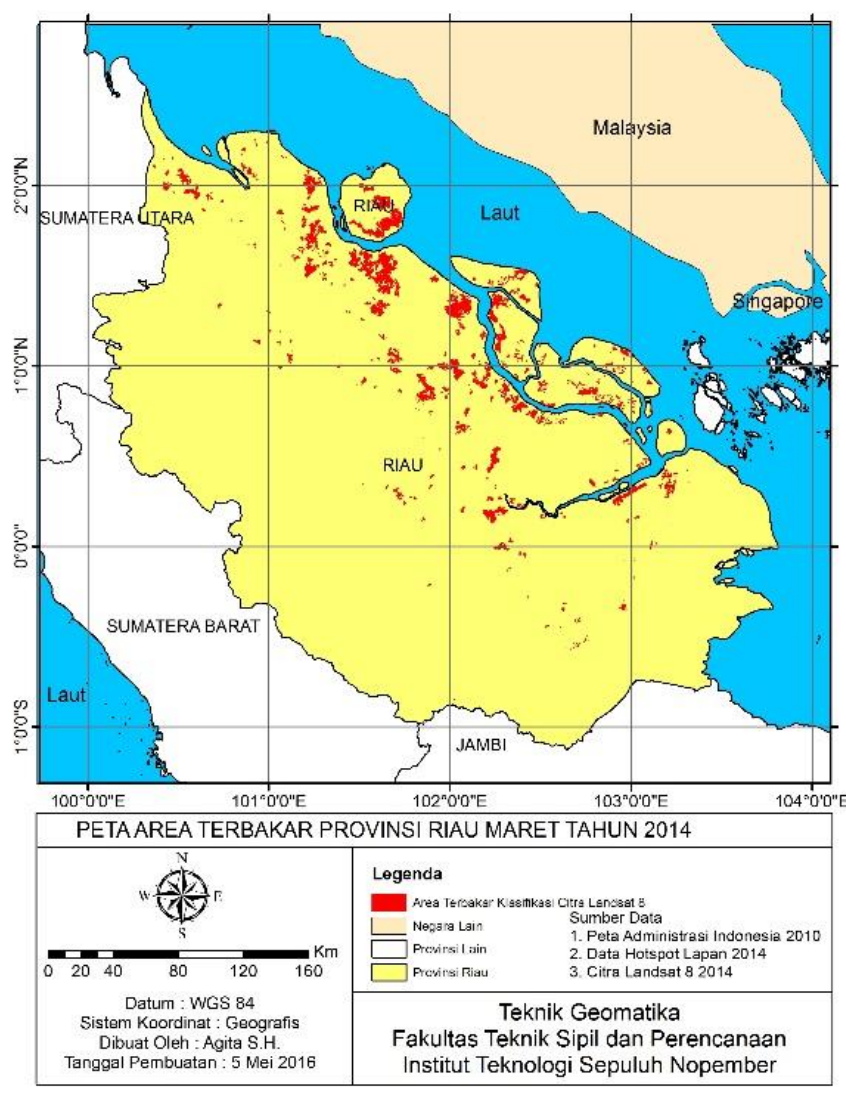

Gambar 9. Area terbakar citra Landsat $830 \mathrm{~m}$

Dari hasil identifikasi area terbakar pada kedua citra tersebut, maka didapatkan perbedaan hasil luasan area terbakar pada masing-masing daerah dan hasil luasan area terbakar seluruh Provinsi Riau. Luas area terbakar Provinsi Riau pada citra MODIS adalah 171045.154 Ha sedangkan luas area terbakar pada citra Landsat 8 adalah $125923.790 \mathrm{Ha}$. Berikut adalah tabel perbandingan luas area terbakar pada masing - masing daerah:

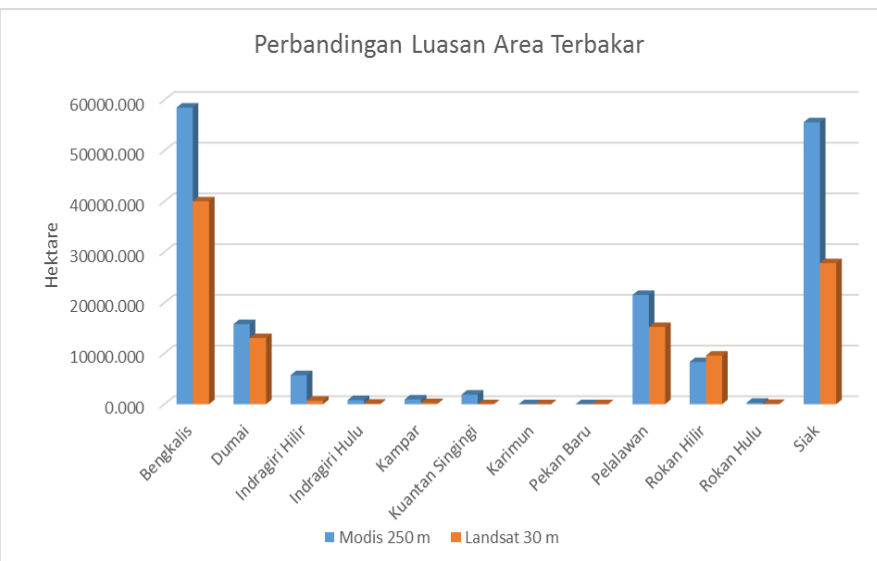

Gambar 10. Perbandingan luasan area terbakar

Tabel 5.

Luasan Area Terbakar Tiap Kabupaten dan Kota

\begin{tabular}{ccc}
\hline \hline Kabupaten & $\begin{array}{c}\text { MODIS } 250 \mathrm{~m} \\
(\mathrm{Ha})\end{array}$ & Landsat 30 m (Ha) \\
& $58.502,386$ & $40.011,077$ \\
Bengkalis & $15.791,747$ & $13.056,898$ \\
Dumai & & \\
\hline \hline
\end{tabular}

\begin{tabular}{ccc}
\hline \hline Indragiri Hilir & $5.724,162$ & 677,985 \\
Indragiri Hulu & 808,929 & 105,465 \\
Kampar & 939,219 & 226,457 \\
Kuantan Singingi & $1.881,651$ & 0 \\
Karimun & 0 & 0 \\
Pekan Baru & 0 & 0 \\
Pelalawan & $21.546,530$ & $15.222,864$ \\
Rokan Hilir & $8.314,721$ & $9.577,771$ \\
Rokan Hulu & 281,250 & 47,950 \\
Siak & $55.611,228$ & $27.806,299$ \\
\hline \hline
\end{tabular}

\section{Penilaian Akurasi}

Penilaian akurasi dilakukan dengan membandingkan data hasil klasifikasi area terbakar dari citra satelit resolusi rendah terhadap hasil delineasi maupun klasifikasi area terbakar dari citra satelit resolusi yang lebih baik.

Burned area agreement merupakan area terbakar yang disetujui dari perpotongan hasil klasifikasi area terbakar citra satelit dan area terbakar referensi dan dinyatakan sebagai batas akurat perimeter api [2]. Secara umum burned area agreement merupakan area hasil klasifikasi daerah terbakar yang saling berpotongan satu sama lain antara kedua citra yang memiliki resolusi yang berbeda.

Related omission error merupakan area terbakar dari area terbakar referensi yang berkaitan dengan batas akurat perimeter api [2].

Related commission error merupakan area terbakar dari hasil klasifikasi area terbakar citra satelit yang berkaitan dengan batas akurat perimeter api [2].

Unrelated omission error: area terbakar dari area terbakar referensi yang tidak berkaitan dengan perimeter api [2].

Unrelated commission error: area terbakar dari klasifikasi area terbakar citra satelit yang tidak berkaitan dengan perimeter api [2].

Dari hasil pemrosesan spasial didapatkan hasil sebagai berikut:

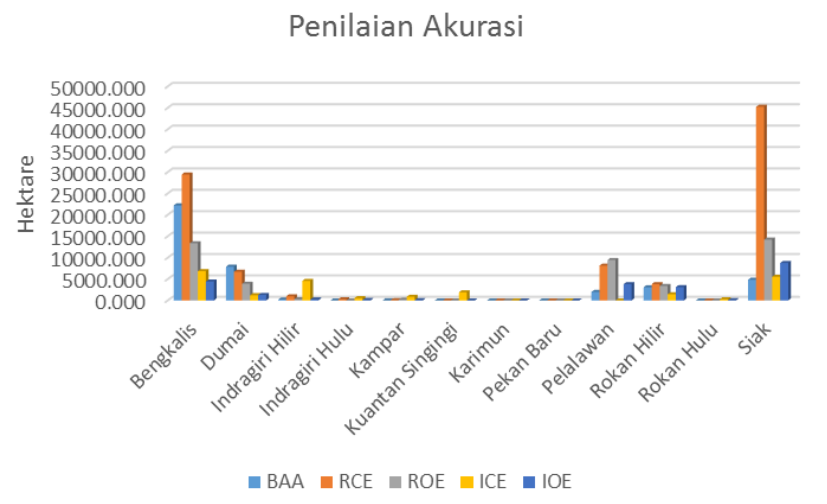

Gambar 11. Penilaian akurasi

Dimana:

$\mathrm{BAA}=$ burned area agreement

$\mathrm{RCE}=$ related commission error

$\mathrm{ROE}=$ related omission error

ICE $=$ independent commission error

$\mathrm{IOE}=$ independent omission error

Dari hasil data diatas apabila ditampilkan dalam tabel maka dapat diketahui luasan masing-masing sebagai berikut: 
Tabel 5.

Luasan penilaian akurasi

\begin{tabular}{cc}
\hline \multicolumn{2}{c}{ Luasan penilaian akurasi } \\
\hline \hline BAA & $40.200,882$ \\
RCE MODIS & $94.633,149$ \\
ROE Landsat 8 & $44.744,897$ \\
ICE MODIS & $23.165,602$ \\
IOE Landsat 8 & $21.766,780$ \\
\hline \hline
\end{tabular}

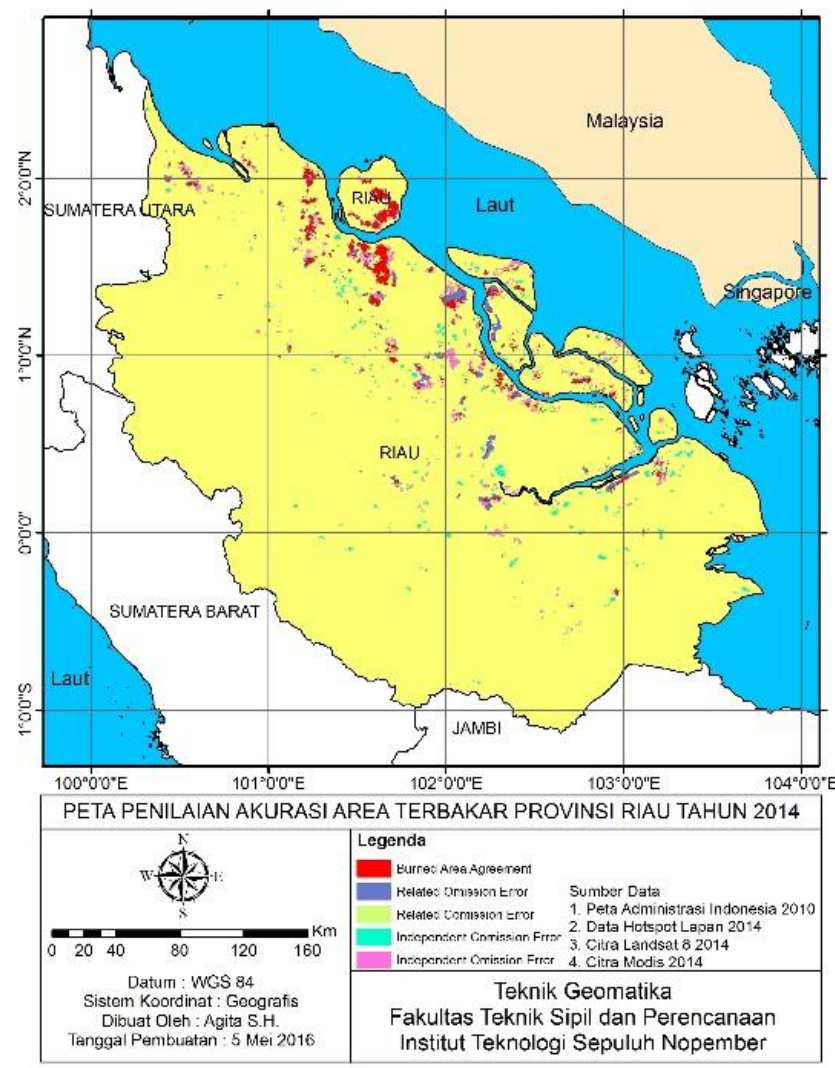

Gambar 12. Peta penilaian akurasi

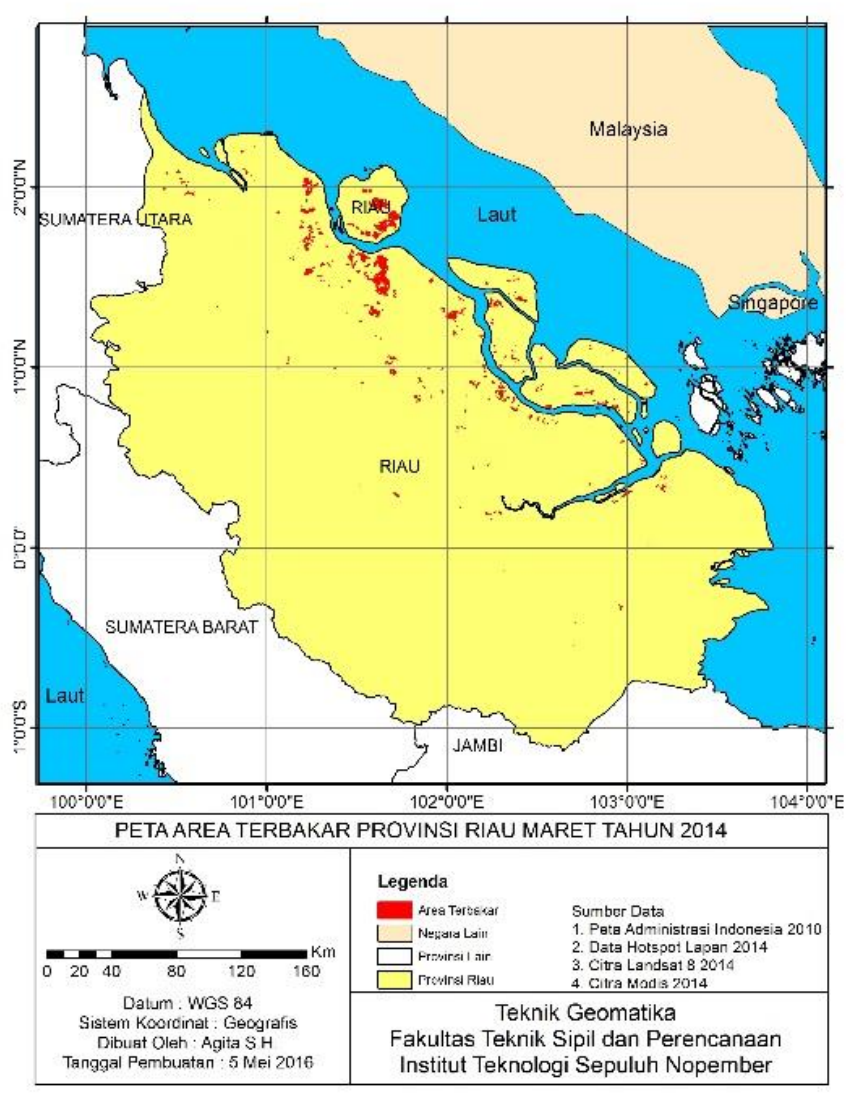

Gambar 13. Peta area terbakar Provinsi Riau

\section{KESIMPULAN DAN SARAN}

Kesimpulan dari penelitian ini adalah sebagai berikut:

a. Luas area terbakar hasil klasifikasi citra Landsat $830 \mathrm{~m}$ adalah 125.923,790 Hektar dengan nilai luasan terbesar berada pada Kabupaten Bengkalis dengan area terbakar seluas 40.011,077 Hektar dan nilai luasan terkecil berada pada Kabupaten Rokan Hulu seluas 47,950 Hektar

b. Luas area terbakar hasil klasifikasi citra MODIS $250 \mathrm{~m}$ adalah 171.045,154 Hektar dengan nilai luasan terbesar berada pada Kabupaten Bengkalis dengan area terbakar seluas 58.502,386 Hektar dan nilai luasan terkecil berada pada Kabupaten Rokan Hulu seluas 281,250 Hektar.

c. Berdasarkan hasil penilaian akurasi dari citra MODIS dan citra Landsat 8 didapatkan hasil luas burned area agreement 40.200,882 Hektar, related comission error 94.633,149 Hektar, related omission error 44.744,897 Hektar, independent comission error 23.165,602 Hektar, dan independent ommission error $21.766,780$ Hektar.

Saran yang dapat diambil dari penelitian ini adalah sebagai berikut:

a. Untuk pemetaan area terbakar skala Provinsi, lebih baik digunakan citra MODIS. Hal ini dikarenakan daerah cakupan cukup luas dengan resolusi spasial $250 \mathrm{~m}$ dan resolusi temporal 1 hari sehingga cukup sesuai untuk pemantauan area terbakar. 


\section{PENUTUP}

Penulis menyadari bahwa laporan ini masih banyak kekurangan baik dalam penulisan maupun isi dari laporan ini, karena itu kami sangat mengharapkan saran dan kritik yang membangun guna perbaikan kelak. Akhir kata, penulis menyampaikan banyak terima kasih.

\section{DAFTAR PUSTAKA}

[1] Suwarsono. 2013. Pengembangan Model Identifikasi Daerah Kebakaran Hutan dan Lahan (Burned area) Menggunakan Citra MODIS di Kalimantan. Jakarta: Lembaga Penerbangan dan Antariksa Nasional.

[2] Olivia, Patricia., 2011. Burned area mapping with MERIS post-fire image. USA: University of Maryland.

[3] Suwarsono. 2012. Daerah Kebakaran Hutan dan Lahan (Burned area) di Kalimantan. Jakarta: FMIPA Universitas Indonesia. 